\title{
"Scarcely in the Twilight of Liberty": Empathic Unsettlement in Charles Chesnutt's The Conjure Woman
}

\author{
Maureen McKnight
}

The colored people of this country are just now passing through a trying period in their history, a history full of trying situationsa dark and gloomy record, with only here and there a flash of light. Even now they are scarcely in the twilight of their liberties. All over the country they are the victims of a cruel race prejudice, the strength and extent of which none but cultivated, self-respecting colored people can rightly apprehend.

-Charles Chesnutt

The colored people of this country are bound to keep the past in lively memory til justice shall be done them.

-Frederick Douglass

David W. Blight explains in Race and Reunion: The Civil War in American Memory that, by the late-nineteenth century, the central motivation underwriting official versions and the memory of the Civil War was "harmonious forgetfulness" (205). At a time when the south, as W. E. B. Du Bois put it, "was awakening as from some wild dream to poverty and social revolution" (67), questions regarding justice were preempted at once by the economic challenges of the post-War era and the mutually enforcing ideologies of nationalism, industrialization, and white supremacy_ideologies that

Maureen McKnight is Assistant Professor of English at the Milwaukee School of Engineering. Her research focuses on the cultural work of memory in American regionalist writers of the nineteenth and twentieth centuries. 
encouraged historical amnesia as they coalesced around modernity.

There was much to be forgotten, and that amnesia was to be violently coerced when necessary. ' In its place, the ideology of the newly created "Old South" came to dominate not only people's daily behaviors but also their personal and collective memories. As such, the Lost Cause was born. ${ }^{2}$ Lost Cause ideology emerged in the 1880s, and it depicts the fantasy "of the Old South's plantation world of orderly and happy race relations" (Blight, Race 211). With the south eager to reclaim authority after its defeat, and with the north inclined to romanticize the brutality of antebellum life for African Americans, slavery became, as Blight argues, "everyone's and no one's responsibility" (205). In other words, America's "bloody racial history was to be banished from consciousness" (205). Rollin G. Osterweis asserts that by 1880 "Reconstruction was becoming a memory and the Myth of the Lost Cause was burgeoning" (10). Though it began as a form of personal memory, it soon became a dominant mode of national memory, for, in the decades that followed, the Lost Cause ideology had, for postbellum white culture in particular, developed into "a nexus of related myths" (ix). ${ }^{3}$ This civil religion influenced memory of the Civil War to such an extent that, as Philip Dray points out, the post-Reconstruction "era saw a flourishing of sentimental nostalgia among whites over the old days when "folks knew their place"' (74). Southerners' personal memories regarding defeat immediately following the War had transformed, through cultural rituals, civic monuments, and restoratively nostalgic literature, into collective, national memories that were invested in the myth of the Old South. ${ }^{4}$

This mythology was popularized through the plantation school of literature, a genre that made available, through different enactments of personal and cultural amnesia, a race-based reconciliation among both southern and northern whites regarding the causes and motives of the Civil War:

\begin{abstract}
As views toward black Americans hardened, attitudes toward the former Confederacy softened, and a powerful impulse toward reunion spread in the land. The South - defanged and shorn of slavery - began to seem appealingly exotic, for as life in the North became more complex, the simple charms of Southern life, its dominant Anglo-Saxon nature, its ruralness, its tradition of genteel aristocracy, came to possess new allure. If, as it was said, the Civil War had been a war between the future and the past, and the future had won, the past could still look awfully good at times. (Dray 51)
\end{abstract}

The plantation school was characterized by Thomas Dixon's popular The Leopard's Spots (1902), The Clansman (1905), and The Traitor (1907), three novels that, like the novels of John Esten Cooke following the War, romanticized the myth of the Lost Cause. 5 This popular, insidious, and, as Blight puts it, "nostalgic Lost Cause" ideology for the antebellum era "reinvigorated white supremacy" by "promoting reminiscences of the faithful slave as a central figure in the Confederate war" (Race 274). Cultural changes that resulted from the War, as well as the coming "age of machines, rapid urbanization, and labor unrest, produced a huge audience for a literature of escape into a pre-Civil War, exotic South" (211). This escapist urge resulted in "[t]housands of readers" taking "sentimental, imaginative journeys 
Southward and into idealized war zones, guided and narrated by faithful slaves" $(211)^{6}$

An amalgamation of two ideas, nostalgia comes from the Greek nostos, to return home, and algos, a painful condition. ${ }^{7}$ As John Frow explains, by the nineteenth century nostalgia "had been extended to describe a condition of estrangement, a state of ontological homelessness which became one of the period's key metaphors for the condition of modernity" (79-80). This emotional response thus broadly signals those attempts to negotiate new territories, either of place, feelings, or thought ${ }^{8}$ Those territories must be negotiated through narrative, for it is through narrative that nostalgia fashions the past as temporally distinct. Nicholas Dames understands that one of nostalgia's "unique characteristics is its ability to act as a narrative, to act in time as well as on time" (13). All narratives of nostalgia, Dames explains, might be broadly characterized "as the set of sites and temporal processes that reflect, and manage, dislocation-experiences of dissonance, disconnection, separation from past spaces and certainties" (12). Dislocation, Dames points out, "is the dilemma nostalgia is invented to solve" (12). In other words, nostalgia is a response to the desire for a sense of home or emplacement.

Svetlana Boym builds on this understanding, importantly distinguishing between two narratives of nostalgia that manage feelings of dislocation quite differently. One mode of nostalgia she calls "restorative," while the other is more critical and self-aware, a nostalgia she calls "reflective." In researching nostalgia after the demise of the Soviet Union, Boym bases her distinction on the etymology of the term nostalgia, explaining the difference between nostos and algia. Restorative nostalgia, Boym argues, "attempts a transhistorical reconstruction of the lost home," while reflective nostalgia "thrives in algia, the longing itself, and delays the homecoming-wistfully, ironically, desperately" (xviii). Moreover, restorative nostalgia "does not think of itself as nostalgia, but rather as truth and tradition," while reflective nostalgia "dwells on the ambivalences of human longing and belonging and does not shy away from the contradictions of modernity" (xviii). In narrating a separable temporal space in which the "past" can critique the "present," a reflective mode of nostalgia is thus both a complicated emotion and a complex relation to history. ${ }^{10}$

Late-nineteenth-century writers of regionally inflected stories challenge the pleasure resident in a restorative nostalgia, directing their readers, through varying modes of nostalgia, to contemplate the past feelingly and reflectively. As Boym argues, a reflective nostalgia "is a form of deep mourning that performs a labor of grief both through pondering pain and through play that points to the future" (55). I examine here a reflective nostalgia that performs labors of grief, interpreting the past in a way that specifically ponders the traumas resulting from the Lost Cause ideology emergent during the Reconstruction. As Dominick LaCapra points out, trauma "indicates a shattering break or cesura in experience which has belated effects" (186). He contends that the project of writing trauma "involves processes of acting out, working over, and to some extent working through in analyzing and 'giving voice' to the past-processes of coming to terms with traumatic 'experiences,' limit events, and their symptomatic effects that achieve articulation in differ- 
ent combinations and hybridized forms" (186). I argue that Charles Chesnutt's novel The Conjure Woman works through the traumas or shattering experiences of the Civil War, its causes, and its aftermath, seeking not only to educate his readers about the brutal realities of plantation life but also to challenge his readers' faith in Lost Cause mythology. As such, the type of nostalgia I analyze resists the "reminiscence industry" that Blight describes to work through and come to terms with the belated effects of the Civil War and Reconstruction. Pedagogically, then, Chesnutt fashions a mode of nostalgia that challenges his readers' racialized and amnesiac memories about pre- and post-Civil War life.

In The Conjure Woman, Chesnutt repeatedly employs a double narrative that enables him, via sympathetic characterization, to unsettle his readers. This strategy invites the reader to compassionately reconsider the reality of black life during slavery and the Reconstruction. In this way, Chesnutt asks his readers to challenge Lost Cause ideology and its romanticization of antebellum life. He evokes and critiques a restoratively nostalgic interpretation of plantation culture to demystify its romanticism, to challenge the fantasy of "faithful," happy slaves, and to insist on the material realities of African Americans not only before but also following the War.

\section{Responding to Lost Cause Ideology}

In his 1931 article "Post-Bellum-Pre-Harlem" Chesnutt reflects on the publication and reception of The Conjure Woman in 1899 as well as the increasing number of literary opportunities available to African-American writers during the intervening years (see McWilliams). Chesnutt had received critical acclaim early in his career, but after "his last two novels were poorly received, probably for their indictment of the Jim Crow South," he returned to his law practice and stenography business, publishing infrequently thereafter (Hemenway 286). With "Post-Bellum-Pre-Harlem" Chesnutt seeks to position himself within the continuum of African-American literary history, distinguishing himself from postbellum plantation fantasy writers such as Thomas Nelson Page and Joel Chandler Harris and explaining to his contemporaries that, at the turn of the twentieth century, "a literary work of an American of acknowledged color was a doubtful experiment" (103). ${ }^{12}$ It was a "doubtful experiment" for both author and publisher because of, as Chesnutt says in "A Multitude of Counselors," the "cruel race prejudice" at work in America (32).

In part, Chesnutt's reflections on his status in American literature are, as Eric Sundquist says, "dedicated to the promotion of his own career as a writer" (441) ${ }^{13}$ However, Chesnutt's interest in positioning himself as situated between the Civil War and the Harlem Renaissance bespeaks his "strikingly complicated relation" (442) to postbellum memory, for, while his early work stands in relation to slave narratives, tales of conjuring, folklore, and regionalism, his later reception stands in relation to the Harlem Renaissance and its "protest" fiction (see Keely).

Chesnutt thus represents a crucial pivot in American cultural life regarding Civil War memory and African Americans' fight for both full citizenship and freedom from prejudice. ${ }^{14}$ As the first widely published African-American short story writer, 
Chesnutt not only straddles two monumental epochs in American history but also employs a mode of nostalgia, especially in The Conjure Woman, that reinstalls slavery as central to his readers' memories of the Civil War. Chesnutt's storytelling protagonist, Julius McAdoo, a former slave and expert rhetor, fashions nostalgic tales to inspire sympathy in his audience, including not only the ostensible audience of two white northerners, John and Annie, who moved south during the Reconstruction era for both health and economic advantages, but also the combined audience of white and black readers of regionalist fiction. Through Julius's narrative, embedded as it is within John's, Chesnutt participates in the debate near the turn of the twentieth century regarding appropriate responses to racial prejudice, a debate that revolved around memory and was exemplified by the approaches of Booker T. Washington and Du Bois.

For both Civil War survivors and their children, the Washington-Du Bois debate helped frame the production of and the responses to the War's meaning. Washington's main response to the dominant Lost Cause ideology was accommodationist in scope. As the leader of a widespread and popular movement, Washington published his autobiography Up From Slavery in 1901 after writing many articles about his life and giving, famously, a speech later named the Atlanta Compromise. In that speech, Washington proposed a theory of race relations that was to foretell the remainder of his successful career as an educator at Tuskegee and as the driving force behind the Tuskegee Machine, a "nationwide network of his supporters and lieutenants in every avenue of black life" (Harlan xiv). His belief in personal development rather than direct social confrontation enabled him to generate financial support from those people sympathetic to the plight of African Americans during an increasingly restrictive era. At the same time, however, his accommodationist strategy helped to facilitate race discrimination, for, in encouraging acquiescence to unjust social structures, it seemed to ratify the devastating yet galvanizing rhetoric of white superiority evident in Lost Cause ideology. Blight points out that Washington's reconciliation involved, in part, "purposeful forgetting" (Race 331). As Blight observes, a "segregated society demanded a segregated historical memory" (361).

Du Bois's approach differed markedly from Washington's because he advocated an active remembrance of black history, including distressing material and social realities. ${ }^{15} \mathrm{He}$ was suspicious of the "growing spirit of kindliness and reconciliation between the North and the South after the frightful difference of a generation ago" (91). Though his approach was less popular than Washington's, Du Bois reasoned that if "reconciliation is to be marked by the industrial slavery and civic death of those same black men, with permanent legislation into a position of inferiority," then more radical action must be taken, "even though such opposition involves disagreement with Mr. Booker T. Washington” (91-92). Du Bois rejected Washington's accommodationist approach, taking instead a more historical and confrontational view in imagining how to achieve equality.

Publicly, Chesnutt avoided involvement in this debate. Sylvia Lyons Render says that Chesnutt visibly "championed neither man," realizing "that both these leaders had the same ultimate goals and that one great need of Afro-Americans was 
unity" (391). Despite his inclination toward private discourse, however, Chesnutt implicitly critiques Washington's accommodationist strategy in The Conjure Woman. In this way, his work corresponds to Du Bois's, for in endorsing a more radical approach to challenging Lost Cause ideology, Du Bois "breathed a heavy sigh of tragedy into America's optimistic sense of itself" and brought "the black experience to the center of the story in the age of emancipation" by providing "an alternative vision of the meaning of the Civil War" (Blight, Race 253-254). ${ }^{16}$ Through Julius's poignant stories of slave life, Chesnutt "goophers" his readers through nostalgia, inducing them to listen through the initially pleasurable and amnesiac restoration of the Old South, but then telling tales in which he challenges Lost Cause ideology as "the Old South's plantation world of orderly and happy race relations" (211). Chesnutt thereby reminds his readers powerfully, through an emotional engagement with the past, of the injustices of slavery. ${ }^{17}$ Through Julius's conjuring of feelings associated with the Lost Cause, Chesnutt challenges his readers' inclination toward this romanticized ideology, reminding them, as William Andrews says, of "a world of mean-spirited, penny-pinching masters whose preoccupation with profit limits them to a narrowly utilitarian attitude toward their slaves and life itself" (Introduction xi). Chesnutt thus subtly yet forcefully contends that African Americans were justified in seeking full citizenship. As William Gleason argues, Chesnutt "campaigned for a just present by marshaling counter-memories of an unjust past" (35; see also Molyneaux). He purposefully evokes a reflective nostalgia to engage, unsettle, and finally work through painful postwar memories.

\section{Belated Narratives of Trauma}

Chesnutt establishes a double narrative to direct his readers toward both the relevance of history and the need for suffrage. ${ }^{18}$ In it, Julius is the storyteller and John and Annie are representative audience members. John, as narrator, finds Julius "useful in many ways and entertaining in others" (137), for not only does he tell stories but he also has "a thorough knowledge of the neighborhood" (136). John admits that he and Annie "took quite a fancy to him" (137). Annie, in particular:

takes a deep interest in the stories of plantation life which she hears from the lips of the older colored people. Some of these stories are quaintly humorous; others wildly extravagant, revealing the Oriental cast of the negro's imagination; while others, poured freely into the sympathetic ear of a Northern-bred woman, disclose many a tragic incident of the darker side of slavery. (129-130)

Chesnutt suggests with this passage that at least three perspectives of plantation life are possible, ones that Julius simultaneously invokes: those that entertain, those that titillate, and those that affect audiences more deeply. In "Gray Wolf's Ha'nt," Chesnutt likewise suggests both the plentitude of, and the potential poignancy in, varying narratives of memory. When talking to Julius, John realizes that Julius:

seemed indeed to possess an exhaustless store [of] tales of the old slavery days . . . some weirdly grotesque, some broadly humorous; some bearing the stamp of 
truth, faint, perhaps, but still discernible; others palpable inventions, whether his own or not we never knew, though his fancy doubtless embellished them. But even the wildest was not without an element of pathos-the tragedy, it might be, of the story itself; the shadow, never absent, of slavery and of ignorance; the sadness, always, of life as seen by the fading light of an old man's memory. (168)

Central to each of Julius's stories are both nostalgia and the tragedies of "slavery and ignorance," for Julius realizes these twinned subjects become a catalyst for reflective thought and action. John and Annie, though both moved, have differing reactions to Julius's perspective of the "never absent" shadow of slavery. John's response is more conservative, for he comprehends the purposes of only the first two types of storytelling: entertainment and titillation. As a somewhat sympathetic listener and as a northerner, John disapproves of slavery, yet as an entrepreneur he also appreciates the cheap labor and underdeveloped resources available to him in postbellum North Carolina. Annie, however, as a more sympathetic listener, understands all three ways in which Julius fashions the past. She signifies the northern abolitionist perspective because she is at once detached from, yet curious about, the historical realities of slavery that Julius details. As a result, Annie can be simultaneously amused, educated, and sympathetically influenced-if at times outwitted-by Julius.

\section{Empathic Unsettlement}

Through this double narrative of Julius's and John's stories, then, Chesnutt not only alludes to the wide range of regionalist stories that all share an appeal to nostalgic pathos but also specifically endorses Annie's more sympathetic response over John's utilitarian one. This narrative approach thus enables Chesnutt to effect a goophering of his readers' sympathy, or what LaCapra calls "empathic unsettlement." LaCapra defines empathic unsettlement as that which "poses a barrier to closure in discourse and places in jeopardy harmonizing or spiritually uplifting accounts of extreme events from which we attempt to derive reassurance or a benefit" (41-42). Empathic unsettlement in narrative, as LaCapra sees it, gives voice to a more "desirable empathy" (102) because it "stylistically upsets the narrative voice and counteracts harmonizing narration or unqualified objectification yet allows for a tense interplay between critical, necessarily objectifying reconstruction and affective response to the voices of victims" (109).

In foregrounding Annie's more desirable feelings of sympathy, Chesnutt not only shows that she, more than John, comprehends the multiple traumas at work in postwar memory, but also reveals how romanticized ideologies concerning the past, like the Lost Cause, are socially constructed. Because in memory, LaCapra explains, "one is both back there and here at the same time" (90), Chesnutt can create a present-past setting wherein, as Faulkner famously writes in Requiem for a Nun: "The past is never dead. It's not even the past" (92). In taking up the questions of memory following the Civil War, Chesnutt seeks, through an affecting narrative, reparation for the cruel race prejudice that flourished especially after the 
end of Reconstruction. The present-past he creates in The Conjure Woman, this "duality (or double inscription) of being," as LaCapra puts it, "is essential for memory as a component of working over and through problems" (90). Chesnutt thus employs a reflective nostalgia for antebellum days to "goopher" his audience into imaginatively reconstructing the realities of slave life and of Reconstruction. At the same time, he suggests various strategies of resistance employed by former slaves with which his readers can sympathize, thereby making possible their sympathy later in the story regarding Julius's efforts to resist as well.

For example, Chesnutt empathically unsettles his readers in "The Goophered Grapevine" by making visible the markers of slave traumas and the Civil War through an entertaining yet telling story. One of the major markers of postwar trauma is the necessary rebuilding of the infrastructure and economy. As the story's narrator, John explains that part of his justification in moving to the south was that it was "a sufficient time after the war for conditions in the South to have become somewhat settled" (118). He equivocates in pronouncing the conditions as entirely settled because of the lasting cultural and economic instability of southern life. He therefore perceives himself to be "enough of a pioneer to start a new industry" and opportunistically seeks to cultivate a vineyard because "[s]everal planters thereabouts had attempted it on a commercial scale, in former years, with greater or less success" (119). Though the abandoned plantation "had fallen a victim to the fortunes of war" (120), he sees his chance as an entrepreneur in the "grape-culture" (118). John knows that "like most Southern industries, it had felt the blight of war and had fallen into desuetude" (119). Chesnutt reminds his readers not only of northerners' entrepreneurial aspirations but also of the devastation in the south, disallowing the romanticization of its agrarian ways. He even reminds them that, though the North Carolina town exuded "a calm that seemed almost sabbatic in its restfulness," it also exuded, "the deeper currents of life-love and hatred, joy and despair, ambition and avarice, faith and friendship" (119). This southern town, then, was like any northern one, since these deeper emotions "flowed not less steadily than in livelier latitudes" (119). In challenging his readers through an unromantic impression of the south, Chesnutt urges them to work through the traumas of slavery and the War by making clear their ever-present relevance.

Chesnutt also seeks to unsettle his readers in this story by suggesting the markers of racial hierarchies at work in American culture. John reads in Julius his interracial heritage. He observes that Julius "was not entirely black" and "quite bald," two qualities that, to John, "suggested a slight strain of other than negro blood" (120). John's impression of Julius suggests the highly charged markers of race and ancestry of the time. He observes that there "was a shrewdness in [Julius's] eyes, too, which was not altogether African" (120). Chesnutt shows his readers that Julius literally embodies the violence of the past.

More than other strategies of empathic unsettlement, however, Chesnutt underscores slavery's divisiveness in separating loved ones from each other. In "HotFoot Hannibal," Chloe suffers and dies because she cannot love Jeff, who is "sol' ... South" to a "spekilater" and who "fell ove'boa'd er jumped off'n de steamboat ... en got drownded" (185). In "Dave's Neckliss," a conjure story Chesnutt pub- 
lished in Atlantic Monthly after the publication of The Conjure Woman that was later added to the original collection, Dave loses his love, Dilsey, and his mind because he is wrongly accused of stealing bacon and is forced to wear a ham around his neck. In "Po' Sandy," Chesnutt depicts the tragic tale of Sandy and Tenie who agree, given the inevitability of their future separation, that Tenie should conjure Sandy into a pine tree. As a tree, though, Sandy remains desirable as a commodity. He is chopped down so that Mars Marrabo, like John, could use the wood to build a new kitchen for his wife. Unable to rescue him, Tenie suffers the ordeal of seeing and hearing Sandy, as Julius explains, "all sawed up" (134).

With "Po' Sandy" Chesnutt again brings into relief John's inability to ascertain fully the indictment of slavery resident in the metaphorical meaning of Julius's story. John looks backward but only to seek present-day material advantage. It is Annie who "understands that the issue in Tenie's husband's transformation into a tree is not whether such a thing is literally possible" (Andrews, Introduction xii). As Richard E. Baldwin notes, since Chesnutt "relies heavily on irony, and like any ironic technique it runs the risk that readers will miss the point," Annie's sympathetic response "is developed as a contrasting character in order to reduce this danger" (350). By having Annie comprehend more fully, through a reflective nostalgia, the import of Julius's stories, Chesnutt indicates the exclusive position of John as a white businessman who misunderstands the significance of stories beyond the most literal interpretations. John's ignorance suggests the cruelty inherent in his privilege. Annie herself "listened to this gruesome narrative with strained attention," showing and later speaking of her dismay at a system "under which such things were possible!" (23). Though she is apparently unaware of Julius's financial motives to retain the schoolhouse, she clearly understands, more than John, the extreme anxiety regarding separation-a kind of terror that slavery exacerbates. Through a double narrative of nostalgia, then, Chesnutt challenges his audience to think and feel differently about antebellum days.

\section{Present-Past Reality}

Chesnutt thus consciously depicts a present-past reality through Julius's stories of empathic unsettlement. In "Dave's Neckliss" Chesnutt specifically emphasizes the reflective quality of Julius's nostalgia, writing that he "never indulged in any regrets for the Arcadian joyousness and irresponsibility which was a somewhat popular conception of slavery" (189). Julius uses "the medium of his recollection" as the means by which not only John and Annie but also Chesnutt's audience can "study . . . the simple but intensely human inner life of slavery" (189; see also Stepto). Though John admits that Julius's "way of looking at the past seemed very strange to us," he also discerns that Julius:

would speak of a cruel deed, not with the indignation of one accustomed to quick feeling and spontaneous expression, but with a furtive disapproval which suggested to us a doubt in his own mind as to whether he had a right to think or to feel, and presented to us the curious psychological spectacle of a mind enslaved long after the shackles had been struck off from the limbs of its possessor. (189) 
After some exposure to Julius, John is able to comprehend the internalized racism Julius feels. John thus is able to contemplate whether, for Julius, "the sacred name of liberty ever set his soul aglow with a generous fire" (189). He wonders too whether Julius held "more than the most elementary ideas of love, friendship, patriotism, religion - things which are half, and the better half, of life to us" (189). He even speculates as to whether Julius "even realized, except in a vague, uncertain way, his own degradation" (189). Despite Julius's limitations, John sees, in the "undertone of sadness, which pervaded his stories," "a spark which, fanned by the favoring breezes and fed by the memories of the past, might become in his children's children a glowing flame of sensibility, alive to every thrill of human happiness or human woe" (189). Chesnutt endeavors to craft a nostalgic sensibility suitable not only to his contemporaries but also to those future readers who seek to be nurtured by the past. As Gleason notes, Chesnutt counters "historical amnesia with concrete memories, and [in] doing so . . . Chesnutt's stories challenge the dominant culture's revisionism by articulating revisions of their own" (69).

Through a narrative of the present-past, then, one that empathically unsettles his audience, Chesnutt fashions a reflective nostalgia that challenges Lost Cause ideology as it lays the foundation for a sensibility sympathetic toward civil rights. Julius's memories bring alive the past, not only for him, not only for John and Annie, but also for Chesnutt's contemporary and future audience. Julius's storytelling does more than discourage John from purchasing the land; it effectively humanizes African Americans. In "The Goophered Grapevine," John observes that, when Julius begins to tell the story of the bewitched grapevine:

[a]t first the current of [Julius's] memory-or imagination-seemed somewhat sluggish; but as his embarrassment wore off, his language flowed more freely, and the story acquired perspective and coherence. As he became more and more absorbed in the narrative, his eyes assumed a dreamy expression, and he seemed to lose sight of his auditors, and to be living over again in monologue his life on the old plantation. (121)

Though his memory and language both "flowed more freely," Julius is required to recall a story originating in his life before freedom. John's description of Julius's reverie is disturbing because it reiterates the fantasy of contented slaves in the Old South. Nevertheless, by voicing a freedman's perspective at a time when white culture assumed superiority, Chesnutt delves into the "intensely human inner life of slavery." It is also, of course, Julius's self-interested attempt to protect his "respectable revenue from the product of the neglected grapevines" (128). Nevertheless, Julius affects John and Annie through his storytelling because, though they eventually purchase the land used by Julius, they continually seek his advice and company. Additionally, John and Annie receive more than just agricultural information as they invest themselves in the outcome of his tale; they learn about the systemic violence of slavery. Chesnutt's readers thus come to understand, along with John and Annie, the unethical economics of lower-class white slave owners, how many of them were of Scottish descent, how difficult and degrading the work was for slaves, how they were treated like chattel, and yet how they persevered 
regardless.

Julius repeatedly uses his stories of slavery to affect the present. Gleason insightfully argues that "in Chesnutt's hands the landscape of slavery could function as an instructive site of both remembrance and resistance in the late nineteenth century, at the very moment that American collective memory, energized by resurgent national myths of racial superiority, aggressively sought to muffle that landscape in pastoral nostalgia" (69). In "Mars Jeems's Nightmare," for instance, Julius tells the story of a slave owner, Mars Jeems McLean, who was conjured into a slave on his own plantation. With this story, Julius at once describes the cruelties of slavery and influences Annie into giving his rather lazy grandson, Tom, another chance to work for them. Julius describes Jeems, at the beginning of the story, as a menacing, unforgiving man who forbade his slaves to marry and forced them to work doggedly. He “did n' make no 'lowance fer nachul bawn laz'ness, ner sickness, ner trouble in de min', ner nuffin; he wuz des gwine ter git so much wuk outer eve'y han', er know de reason w'y" (139). Jeems typifies the mentality of a slave owner whose priorities are profit expansion and slave exploitation. After his reversal of fortune, however, he sympathizes with his slaves' conditions. His conversion is not total, for he still maintains the plantation in the end, but it was apparent that “Aunt Peggy's goopher had made a noo man un 'im enti' ely" (147). Julius intends for Jeems transformation to influence Annie, for he anticipates that she will resist any resemblance to Jeems's early, unsympathetic feelings toward workers. He therefore conjures in Annie an interested and sympathetic response, indirectly yet effectively persuading her into not using the schoolhouse lumber for her new kitchen and into rehiring his grandson Tom.

While conjuring can be a powerful conversion tool for the good, Chesnutt does not, however, romanticize its effects, acknowledging even internal strife among African Americans. Andrews notes that, on occasion, "conjure is not put to such pleasing purposes; it becomes a means of wreaking vengeance in internecine struggles between slaves and free blacks" (Introduction xi). In "Gray Wolf's Ha'nt," for instance, after the slave Dan accidentally kills a "free nigger man," as Dan's wife Mahaly describes him (169), Dan falls prey to the workings of the free man's father, Jube, a conjurer. Julius describes Dan as "good-nachu'd most er de time, but dange' ous ter aggervate," especially if another black person was to "fool wid" him (168). With this story, Chesnutt does not avoid internal power struggles among African Americans. Instead, he depicts Dan's and Jube's subsequent and ultimately fatal distrust of each. Seeking revenge, Jube sends a rattlesnake to bite Dan, a "jay-bird fer ter put p'isen in Dan's vittles," and "rheumatiz, so he could n' git 'is han' ter his mouf ter eat, en would hafter sta've ter def" (170). None of these techniques work, so a final confrontation results, in which Jube tricks Dan into becoming a wolf, forcibly turns Mahaly into a black cat, and gets Dan to kill Mahaly, believing the black cat haunts him. In one last conjure, Jube tricks Dan into drinking a "mixtry" that permanently makes him a wolf (174). Dan is incredulous because he "nebber 'lowed fer a minute dat [Jube] would lie wid his las' bref" (174). In "The Gray Wolf's Ha'nt," Chesnutt acknowledges not only the internecine struggles at work in the antebellum era but also the evil possible in conjuring. Furthermore, 
Julius ends his story by making clear that, rather than being saddened by the loss of Dan and Mahaly, "Mars Dugal' tuk on a heap 'bout losing' two er his bes' han's in one day" (175). Emphasizing the all too real ideology of plantation life, Julius explains to John and Annie that, since "dat fall de craps wuz monst' us big . . . Mars Dugal' say de Lawd had temper' de win' ter de sho'n ram, en make up ter 'im fer w'at he had los" (175). A romanticized depiction of plantation life, internalized race struggles, or conjuring would undermine Chesnutt's social commentary. He carefully avoids the fantasized niceties of plantation life by depicting more fully the "tragedy," the "shadow," and the "sadness" of slavery (168).

And, in these stories that reflect on the material reality of both antebellum and postbellum life, Julius occasionally reaps the rewards of his imaginativeness. In "The Gray Wolf's Ha'nt," John discovers, on the property haunted by Dan, "a beetree ... with an ample cavity in its trunk," giving him reason to believe that "Julius had been getting honey from this tree" and that his story "doubtless proved useful in keeping off too inquisitive people, who might have interfered with his monopoly" (176). In "The Conjurer's Revenge," Julius convinces John not to buy a mule, as John would like, but to buy instead a horse. Julius accomplishes this feat with a story about a "metamorphosed unfortunate" (157) who is only partially conjured from a mule into a human. Though Annie listens "with only a mild interest" at a story she says "is n't pathetic" and "has no moral" (156), John "was glad to have the monotony of Sabbath quiet relieved by a plantation legend" (150). John later comes to understand, after buying what turns out to be a "worthless, brokenwinded, spavined" horse suggested to him by Julius, "that Julius may have played a more than unconscious part in [the] transaction" (157). In this way, Chesnutt creates a more mischievous character in Julius than Harriet Beecher Stowe does, for example, in Uncle Tom. Through his stories, Julius not only inspires noble sympathies but also affords for himself "a new suit of store clothes" that exuded a "striking originality of cut and pattern" (157).

Despite this personal advantage, however, Julius also entertains John and Annie for more beneficent reasons. In "Sis' Becky's Pickaninny," for instance, Annie suffers from a melancholy for which John can find no cure. Julius tells a story in which he ostensibly explains why he believes that carrying a rabbit's foot brings good fortune. John makes clear that "this curious superstition" had not yet "attained its present jocular popularity among white people" (158). It did involve, however, "the charm of novelty," so, hoping that it will amuse Annie, John prompts Julius into a story. Annie listens "with greater interest than she had manifested in any subject for several days" (165). Concerned for her health, John watches her "furtively from time to time during the recital," observing that her face expressed "in turn sympathy, indignation, pity, and at the end lively satisfaction" (165). Thus engaged, Annie's "condition took a turn for the better from this very day, and she was soon on the way to ultimate recovery" (166). After several weeks pass, however, John discovers in Annie's dress pocket the rabbit's foot Julius had carried. Julius's conjuring not only educates John and Annie as to the injustices of slavery, moving them both toward the goals of emancipation, but also inspires in Annie a literal recovery. In a similar way, too, Julius's stories inspire in Chesnutt's readers a 
recovery, one not only of reparative healing of past traumas but also one that recuperates the past more fully to include non-dominant perspectives.

\section{Negotiating Trauma}

As a means of empathic unsettlement, The Conjure Woman negotiates and therefore rewrites traumas of race in America. By working through recollections of painful events regarding former slaves' rights to citizenship, and showing these memories to be negotiable, Chesnutt updates nostalgia's mode of reconciliation. He thus implicitly challenges Washington's accommodationist approach by fashioning a nostalgia that plays quite seriously with trauma's significance. Du Bois suggests that the "saddest" aspect of former slaves and their owners, or "figures of the present-past," was their mutual hate, a bitter emotion passed on to future generations (68-69). Because the former slave owner, Du Bois explains, "had fought with desperate energy to perpetuate" slavery and because the former slave understands this fact, the "cleft between the white and black South grew" (68). Like Du Bois, Chesnutt recognizes this cleft and therefore evokes, through a double narrative of nostalgia, a present-past to bring into relief the primacy of race in relation to Civil War memories, seeking reconciliation based not on white supremacy but on African Americans' traumatic experiences.

The reparative work of reunification after the Civil War involved more than a consolidation around white supremacy. It involved the working through of deeply felt and repressed traumas regarding the recent past by not only the general population but also-and especially-African Americans. Cathy Caruth understands that trauma "is always the story of a wound that cries out, that addresses us in the attempt to tell us of a reality or truth that is not otherwise available" (4). Giving voice to the prolonged nature of that trauma, Chesnutt observes in "A Multitude of Counselors" that:

[t]he colored people of this country are just now passing through a trying period in their history, a history full of trying situations - a dark and gloomy record, with only here and there a flash of light. Even now they are scarcely in the twilight of their liberties. All over the country they are the victims of a cruel race prejudice, the strength and extent of which none but cultivated, self-respecting colored people can rightly apprehend. (32)

Not yet in the twilight of liberty, at a time when ex-slaves' personal and cultural memories still evoked painful and even dangerous feelings and when modernity was seduced by amnesia, Chesnutt sought indirect and compelling ways to address the exigencies of the past, if only to capture "here and there a flash of light."

Blight reminds us that "Americans faced an overwhelming task after the Civil War and emancipation: how to understand the tangled relationship between two profound ideas-healing and justice" (Race 3). Following the War and for many decades thereafter, Americans sought to forget the painful past or recast it in light of the newly imagined Old South. Blight acknowledges the importance of both healing and justice, yet admits that, "given the potency of racial assumptions and 
power in nineteenth-century America, these two aims never developed in historical balance" (3). Blight's argument explains "how the forces of reconciliation overwhelmed the emancipationist vision in the national culture, how the inexorable drive for reunion both used and trumped race" (2).

While I agree with his assertion that one kind of reconciliationist vision based on the notion of white supremacy triumphed during much of the century following the Civil War, I resist Blight's broad contention that "sentimental romance won over ideological memory" (4), for he does not adequately consider how regionalist writers such as Chesnutt challenged the Lost Cause mythology through a reflective mode of nostalgia. Certainly, his approach involved less radical challenges to romanticized memories of the Old South than emancipationist ones; however, Chesnutt directs his readers, through pathos, first to humanize cultural others and then to reflect on and reject the plantation fantasies resident in collective and personal memories. In these ways, Chesnutt's project destabilizes tacit endorsements of a white supremacist form of reconciliation.

In The Conjure Woman, Chesnutt unsettles his audience through an empathetic depiction of the indignities and horrors suffered by slaves, an approach that refutes the credibility of plantation fantasies so dominant in Lost Cause ideology. Chesnutt was able, as Andrews contends, "to take a new look at the whites and blacks who were committed to the South's 'peculiar institution,' a look unbiased by the sort of affection and nostalgia [Harris's] Uncle Remus and Page's uncles displayed for their erstwhile masters and their former positions" ("Significance" 380). In contrast to the popular plantation fiction of the era, in which a "benevolent aristocrat and loyal retainer" were depicted, Chesnutt made available for examination "the mundane, everyday life of the slave, the relationship of the master to the ordinary slave, and the attitudes of such a slave to both his daily experience and his seldom-seen master" (380). More than that, in presenting the cruelties and even banality of slavery, Chesnutt disrupted harmonious plantation fantasies by showing the horrors suffered by African Americans. Through a nostalgia that reflects on the construction of the Lost Cause and the Old South, Chesnutt sought to insist that readers include in their understandings of African Americans' lives the painful material realities of plantation life.

As Blight explains, memories of the Civil War and its causes had devolved into "a set of rituals" that had not benefited from critical reflection (Race 97). Chesnutt seeks to rectify that problem not only by articulating past traumas but also by opening contemporary remedies, such as soothing stories of the Lost Cause, to meticulous examination. Finally, Chesnutt fashions an engaged, critical nostalgia as a catalyzing approach to reconciliation, one not based on whiteness, but one that envisions the inequities of the past as fuel for the pursuit of justice in the present and future.

\section{Notes}

${ }^{1}$ Of course the Ku Klux Klan emerged at this time. The KKK employed many kinds of terrorism against African Americans-cruel and unlawful actions that, regrettably, were familiar to former slaves, since the same intimidation strategies had been used before the war, 
during the patroller era (see Dray; Foner).

${ }^{2}$ Wartime journalist Edward Alfred Pollard called the first of his two volumes, published in 1866, The Lost Cause: A New Southern History of the War of the Confederates. Osterweis explains that, while Pollard "may not have been the first to use the term "The Lost Cause' in reference to the Southern defeat, he apparently was responsible for its currency" (11).

${ }^{3}$ Blight argues that the Lost Cause had achieved such a "remarkably wide appeal" that it "became a civil religion" (Beyond 155). Keith S. Bohannon adds that the well-attended ceremonies honoring the memory of the Confederacy" offered a contrast between a "New South" and an "Old South" that further promulgated the belief that something from antebellum days had been lost.

${ }^{4}$ While Americans "were deeply aware of loss in the late 1860s," as Blight points out, they "were not ready to have war depicted in all its savagery" (Race 152). Novels with war themes. for instance, "were not plentiful in American culture before the 1880s" (151).

${ }^{5}$ Osterweis asserts that Cooke was "a sensitive antebellum novelist" who "produced a variety of postwar books" that "glorified the Confederate Cause and castigated its enemies; these included Wearing of the Gray (1867), Hammer and Rapier (1870), and A Life of General Robert E. Lee (1871)" (26).

${ }^{6}$ This ideology captivated American consciousnesses, Blight argues, for it "reinforced Southern pride, nationalized the Lost Cause, and racialized Civil War memory for the postwar generations" (Race 274). Tourism and a newly mobile middle class further fueled these Lost Cause flames. Americans from all regions embarked on tours of the Old South, a place deemed authentic because it was "peopled by gallant men, elegant women, and happy blacks" (Dray 51).

${ }^{7}$ Originally a medical term, the word nostalgia was first used in the seventeenth century by Johannes Hofer, a Swiss doctor. Reference to the physical disease of nostalgia, as T. J. Jackson Lears explains, was further "popularized during the eighteenth century by European physicians, who were struck by Swiss mercenaries' failure to thrive in faraway lands" (59). Nostalgia's initial symptoms thus emerged as primarily physical, as problems resulting from an inability to adapt to both warfare and mobility, transforming only in the middle of the nineteenth and at the beginning of the twentieth centuries into psychological ones. Of course, as Kimberly K. Smith explains, people who lived before the eighteenth century knew homesickness, but nostalgia was invented "in the context of medical/psychological discourse" and in response to modernity (506). As Fred Davis explains, only with nostalgia's "demilitarization and demedicalization" does it come to be seen as a problem of psychology (4).

${ }^{8}$ It was not until the nineteenth century, Boym explains, that nostalgia bifurcated, becoming in part "institutionalized in national and provincial museums and urban memorials" and in part privatized as an individual emotional experience (15).

${ }^{9}$ In a similar categorization, Davis distinguishes between "First Order or Simple Nostalgia, Second Order or Reflexive Nostalgia, and Third Order or Interpreted Nostalgia" (17). While I appreciate Davis's attempt to add nuance to an understanding of nostalgia, I prefer Boym's two-part model because I want to make clear that a reflexive nostalgia always already involves a critical interpretation of history's constructedness. I also do not wish to create an unnecessary hierarchy of various modes of nostalgias, since I seek to examine the cultural work of this response rather than classify one reflective mode as more effective than another.

${ }^{10}$ In contrast, restorative nostalgia, the kind that "protects the absolute truth" (Boym

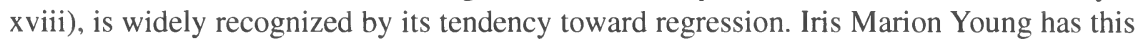
mode of nostalgia in mind in Intersecting Voices: Dilemmas of Gender, Political Philosophy, 
and Policy. Fredric Jameson similarly criticizes this type of relation to the past in his description of nostalgia as a "mesmerizing new aesthetic mode" that "emerged as an elaborated symptom of the waning of our historicity, of our lived possibility of experiencing history in some active way" (21). Jameson's reference to nostalgia's "insensible colonization of the present" is by now "canonical," as Chris Bongie puts it (215), and Jameson's kind of denunciation of nostalgia has been, until recently, as widespread as it has been categorical. Renato Rosaldo also criticizes what can be seen now as a restorative form of nostalgia when he admonishes its function as a dominant feature of imperialism, explaining that it is "a particularly appropriate emotion to invoke in attempting to establish one's innocence and at the same time talk about what one has destroyed" (70). At the same time Rosaldo persuasively insists that an imperialist form of nostalgia masks privilege rather than reveals it, however, he also, along with other critics, conflates this mode of nostalgia with its more reflective forms.

${ }^{11}$ William Gleason explains that, by 1889 , Chesnutt was "the first African American fiction writer to be published" in the Atlantic Monthly (33). For more information regarding Chesnutt's ambitions during the 1880s and 1890s, see Brodhead 177-210.

${ }^{12}$ For further discussion regarding Chesnutt's relation to plantation fiction, see Andrews, "Significance." Andrews understands how the "aristocratic ideal revered by Page and his followers was not merely the nostalgic memory of a confirmed reactionary; it was proposed as a viable means of leading the South out of the chaos of Reconstruction" (384). Andrews also sees how Chesnutt resists such a regressive nostalgia.

${ }^{13}$ For more biographical information, see Helen Chesnutt's Charles Waddell Chesnutt.

${ }^{14}$ Blight observes that the late-nineteenth-century triumph of reconciliationist over emancipationist vision "does not merely dead-end in the bleakness of the age of segregation," and the call for emancipation does not die "a permanent death on the landscape of Civil War memory" (Race 2).

${ }^{15}$ For instance, Du Bois details the "resistless feeling of depression" that he experiences when visiting Georgia, "the Cotton Kingdom," which is "the shadow of a marvelous dream" (146). He notes how "curious a land this is,--how full of untold story, of tragedy and laughter, and the rich legacy of human life; shadowed with a tragic past, and big with future promise!" (150).

${ }^{16} \mathrm{Du}$ Bois confronts his readers, asking them to remember "the swarthy spectre" of racism still plaguing the nation (48). America "has not yet found peace from its sins," Du Bois argues, because "the freedman has not yet found in freedom his promised land" (48).

${ }^{17}$ Hemenway points out that there "is no standard definition of conjure" or goophering (n304), but he would agree with Alan Dundes, who says, "[t]o be 'goofed' is to be under the influence of marijuana and 'to goof,' meaning to make a mistake, was originally a jazz term. Both of these meanings are not that different from being 'under the influence' of a magical agent" (n371).

${ }^{18}$ For more information on how Chesnutt's use of a double narrative enables readers to hear two race-inflected versions of the stories, see Britt and Ferguson.

\section{Works Cited}

Andrews, William L. Introduction. Collected Stories of Charles W. Chesnutt. By Charles W. Chesnutt. Ed. Andrews. New York: Penguin, 1992. vii-xvii.

- . "The Significance of Charles W. Chesnutt's 'Conjure Stories." Chesnutt, Selected Writings, 370-387.

Baldwin, Richard E. "The Art of The Conjure Woman." Chesnutt, Selected Writings, 346-357. Blight, David W. Beyond the Battlefield: Race, Memory, and the American Civil War. 
Amherst: University of Massachusetts Press, 2002.

—. Race and Reunion: The Civil War in American Memory. Cambridge: Harvard University Press, 2001.

Bohannon, Keith S. “'These Few Gray-Haired, Battle-Scarred Veterans': Confederate Army Reunions in Georgia, 1885-95." The Myth of the Lost Cause and Civil War History. Ed. Gary W. Gallagher and Alan T. Nolan. Bloomington: Indiana University Press, 2000. 89-109.

Bongie, Chris. "A Street Named Bissette: Nostalgia, Memory, and the Cent-Cinquantenaire of the Abolition of Slavery in Martinique (1848-1998)." South Atlantic Quarterly 100.1 (2001): 215-257.

Boym, Svetlana. The Future of Nostalgia. New York: Basic Books, 2001.

Britt, David D. "Chesnutt's Conjure Tales: What You See is What You Get." Chesnutt, Selected Writings, 358-369.

Brodhead, Richard. Cultures of Letters: Scenes of Reading and Writing in NineteenthCentury America. Chicago: University of Chicago Press, 1993.

Caruth, Cathy. Unclaimed Experience: Trauma, Narrative, History. Baltimore: Johns Hopkins University Press, 1996.

Chesnutt, Charles W. Selected Writings. Ed. Sally Ann H. Ferguson. Boston: Houghton Mifflin, 2001.

Chesnutt, Helen. Charles Waddell Chesnutt: Pioneer of the Color Line. Chapel Hill, NC: University of North Carolina Press, 1952.

Dames, Nicholas. Amnesiac Selves: Nostalgia, Forgetting, and British Fiction, 1810-1870. Oxford: Oxford University Press, 2001.

Davis, Fred. Yearning for Yesterday: Nostalgia, Art, and Society. New York: Free Press, 1979.

Dray, Philip. At the Hands of Persons Unknown: The Lynching of Black America. New York: Random House, 2002.

Du Bois, W. E. B. The Souls of Black Folk. 1903. New York: Penguin Putnam, 1995.

Dundes, Alan. Mother Wit from the Laughing Barrel: Readings in the Interpretation of AfroAmerican Folklore. Englewood Cliffs, NJ: Prentice-Hall, 1973.

Faulkner, William. Requiem for a Nun. New York: Random House, 1950.

Ferguson, Sally Ann H. "Charles Chesnutt: An American Signifier." Chesnutt. Selected Works 1-11.

Foner, Eric. Reconstruction: America's Unfinished Revolution, 1863-1877. Cambridge: Harper \& Row, 1988.

Frow, John. Time and Commodity Culture: Essays in Cultural Theory and Postmodernity. Oxford: Clarendon, 1997.

Gleason, William. "Chesnutt's Piazza Tales: Architecture, Race, and Memory in the Conjure Stories.” American Quarterly 51.1 (1999): 33-77.

Jameson, Fredric. Postmodernism, Or, The Cultural Logic of Late Capitalism. Durham, NC: Duke University Press, 1991.

Harlan, Louis R. Introduction. Up From Slavery. By Booker T. Washington. New York: Penguin, 1986. vii-xlviii.

Hemenway, Robert. "The Functions of Folklore in Charles Chesnutt's The Conjure Woman." Journal of the Folklore Institute 13 (1976): 283-309.

Keely, Karen A. "Marriage Plots and National Reunion: The Trope of Romantic Reconciliation in Postbellum Literature." Mississippi Quarterly 51.4 (1998): 621-648.

LaCapra, Dominick. Writing History, Writing Trauma. Baltimore: Johns Hopkins University Press, 2001.

Lears, T. J. Jackson. "Looking Backward: In Defense of Nostalgia." Lingua Franca 7.10 (December 1998/January 1999): 59-66. 
McWilliam, Dean. "Charles Chesnutt and the Harlem Renaissance." Soundings: An Interdisciplinary Journal (1997): 591-606.

Molyneaux, Sandra. "Expanding the Collective Memory: Charles W. Chesnutt's The Conjure Woman Tales." Memory, Narrative, and Identity: New Essays in Ethnic American Literatures. Ed. Amritjit Singh et al. Boston: Northeastern University Press, 1994. 164-178.

Osterweis, Rollin G. The Myth of the Lost Cause, 1865-1900. Hamden, CT: Archon Books, 1973.

Pollard, Edward Alfred. The Lost Cause: A New Southern History of the War of the Confederates. New York: E. B. Treat, 1866.

Render, Sylvia Lyons. Charles W. Chesnutt. Boston: Twayne Publishers, 1980.

Rosaldo, Renato. Culture and Truth: The Remaking of Social Analysis. Boston: Beacon Press, 1989.

Smith, Kimberly K. "Mere Nostalgia: Notes on a Progressive Paratheory." Rhetoric and Public Affairs 3.4 (2000): 505-527.

Stepto, Robert B. “'The Simple but Intensely Human Inner Life of Slavery': Storytelling, Fiction and the Revision of History in Charles W. Chesnutt's 'Uncle Julius Stories.'” History and Tradition in Afro-American Culture. Ed. Gunter H. Lenz. Frankfurt: Campus, 1984. 29-55.

Sundquist, Eric. To Wake the Nations: Race in the Making of American Literature. Cambridge: Harvard University Press, 1993.

Young, Iris Marion. Intersecting Voices: Dilemmas of Gender, Political Philosophy, and Policy. Princeton: Princeton University Press, 1997. 